\title{
Evaluation of Jeevamrut and its Constituents against Alternaria Leaf spot of Mungbean in-vitro and under Cage House Condition in Rajasthan
}

\author{
Snehika Pandia ${ }^{1}$, Amit Trivedi ${ }^{1}$, S. K. Sharma ${ }^{2}$ and Shravan Yadav ${ }^{2}$ \\ ${ }^{1}$ Department of Plant Pathology, ${ }^{2}$ Department of Agronomy, Maharana Pratap University of \\ Agriculture and Technology, Udaipur, Rajasthan-313001, India \\ *Corresponding author
}

\begin{tabular}{|l|}
\hline Ke y w o r d s \\
ZBNF, Jeevamrut, \\
$\begin{array}{l}\text { Alternaria alternata, } \\
\text { Jeevamrut-2, } \\
\text { Jeevamrut-1, PEDC }\end{array}$ \\
\hline Article Info \\
\hline $\begin{array}{l}\text { Accepted: } \\
\text { 22 August } 2019 \\
\text { Available Online: } \\
\text { 10 September } 2019\end{array}$
\end{tabular}

A B S T R A C T
Growing inclination towards Zero Budget Natural farming (ZBNF) in India to reduce expenditure on external input and to reduce indebtness of farmers, a study was under taken on evaluation of Jeevamrut, prepared by mixing cow dung, cow urine, pulse flour, jaggery and soil, and its constituents for management of Alternaria leaf spot caused by Alternaria alternata in organic mungbean under cage house condition as well as against the pathogen in-vitro, as the disease is quite destructive in all mungbean growing areas of southern Rajasthan. Among different components and final product of Jeevamrut, Jeevamrut-2 with the protocol as suggested by Palekar, was found most effective in inhibiting $A$. alternata in-vitro with mycelial growth inhibition of 93.34 per cent. Cow urine has also significant inhibitory effect against the test pathogen with mycelial growth inhibition of 92.23 per cent at 7.5 per cent concentration. Out of different organic inputs evaluated as spray applications for management of Alternaria leaf spot of mungbean, foliar spray of Jeevamrut-2 was found effective in managing the disease and also gave maximum PEDC of 75.2 followed by Jeevamrut-1 with 68.6 PEDC.

\section{Introduction}

In an attempt to return back to basics with adoption of natural means of farming to sustain ecosystem, to abate cost of production and to attain the goal of doubling farmers' income, the gravity for Zero budget natural farming $(\mathrm{ZBNF})$ has been realized from the inclusion of this concept in the India's budget
2019-20. Among four pillars of ZBNF, Jeevamrut, given by Palekar, prepared from cow dung, cow urine, pulse flour, jaggery and soil, has been proved to be benefaction for combating various plant diseases. Organic formulations (Jeevamrut, Beejamrut, Panchgavya etc.) utilized by farmers in their fields are not standardized. Mostly they are crude in the sense that proportion of 
constituents of these formulations (cow dung, cow urine, butter milk, pulse flour etc.) are not definite. As a result these formulations are used by farmers, without knowing proper amount of their constituents, leading to derivation of less benefits as compared to use of standardized organic formulations, whose amount of constituents are defined. Mungbean or green gram (Vigna radiata L.) is one of the important pulse crops of India. India is contributing 21.00 per cent global pulses in world production from an area of about 32.00 per cent (Anon. 2016). In Rajasthan, it is cultivated on about 9.03 lakh hectares with total production of 3.63 lakh tones and productivity of $403 \mathrm{~kg}$ per hectare during kharif season (Anon. 2016). Mungbean suffers from many diseases caused by fungi, bacteria, viruses, nematodes. Among them, Alternaria leaf spot of mungbean(caused by Alternaria alternata (Fr.) Keissl.) is one of the important diseases causing economic yield loss of mungbean. The disease was reported from Udaipur, India causing 80 per cent incidence at the age of 65 days and affecting about 45 per cent leaf area (Gupta, 1970). The perusals of review on the constituents reveal that cow urine and dung have got several applications in agriculture. (Basak and Lee, 2002; Nargis et al., 2007; Patil, 2007; Rakesh et al., 2013). Almost no work till date has been done for invitro and in-vivo evaluation of a complete product of Jeevamrut against any pathogen. However, several works related to suppression of fungal diseases by using other organic formulations have been reported. (Reddy and Padmodaya, 1996; Hurali and Patil, 2009). In view of the increasing severity of Alternaria leaf spot in Southern Rajasthan and limited research on organic management of Alternaria leaf spot of mungbean, there is a need for development of information on standardization of Jeevamrut against Alternaria leaf spot of mungbean. Hence, the present investigation was undertaken to evaluate different components and final product of Jeevamrut in amended plain agar media against Alternaria alternata in-vitro and to standardize Jeevamrut in-vivo against Alternaria leaf spot of mungbean in organic pot culture under cage house condition.

\section{Materials and Methods}

Symptoms of Alternaria leaf spot appear as small, light brown lesions on leaves and at the tip or the margins, which later turn grayish to dark brown and dull white in centre. With the age of crop and infection time, the lesions enlarge and may result in 'shot hole' symptoms leading to chlorosis and dropping off of leaves.

\section{Isolation of the pathogen and Pathogenicity test}

Fresh infected leaves of the mungbean plant showing typical symptoms of the Alternaria leaf spot were collected from the farmers' fields from Udaipur for isolation of the pathogen. Infected portions of the leaves were cut into small bits (with a little healthy leaf tissue around) and were surface sterilized with 0.1 percent mercuric chloride for $30 \mathrm{sec}$ followed by series of washings with sterilized water. These bits were transferred aseptically into potato dextrose agar medium contained petriplates. The petriplates were incubated at room temperature $\left(27 \pm 2^{\circ} \mathrm{C}\right)$ (plate1). After 4-7 days of incubation, radiating mycelia growth was observed from the edges of the infected bits. Edge of the fungal colonies were transferred to potato dextrose agar medium slants in a refrigerator at $10^{\circ} \mathrm{C}$ and periodical sub culturing for all the studies was done.

The pathogenicity of the culture was checked by artificially inoculating the mungbean plants grown in earthen pots and by reisolation. The causal organism was identified as Alternaria alternata on the basis of morphological and cultural characteristics. (Simmons, 2007). 
Maintenance of the pathogen Alternaria alternata

The fungus was subcultured on potato dextose agar slants and kept at $27 \pm 2^{0} \mathrm{C}$ for 15 days. Subsequent, subculturing of culture was done at an interval of 20 days. Such isolates were stored in a refrigerator at $4^{0} \mathrm{C}$. The culture was revived periodically.

Potato dextrose agar medium (PDA)

$\begin{array}{ll}\text { Peeled potato } & 250.00 \mathrm{~g} \\ \text { Dextrose } & 20.00 \mathrm{~g} \\ \text { Agar agar } & 20.00 \mathrm{~g} \\ \text { Distilled water } & 1000 \mathrm{ml} \\ \text { pH } & 7.00\end{array}$

Evaluation of Jeevamrut and its constituent amended plain agar media against Alternaria alternata in-vitro

In order to standardize Jeevamrut, three different protocols were used by taking varying concentrations of cow dung and cow urine. Accordingly, Jeevamrut-1, Jeevamrut-2, Jeevamrut-3 were prepared, out of these three protocols, Jeevamrut-2 was kept as has been suggested by Palekar (2006).

All the ingredients were further tested individually in different concentrations by adding plain agar into them. There by making in all twelve treatments.

Jeevaamrut* final composite product,

\section{Preparations of different media}

Jeevaamrut -1 amended plain agar media(as per above)-2.5 g cow dung, $7.5 \mathrm{ml}$ cow urine, $1 \mathrm{~g}$ jaggery, $1 \mathrm{~g}$ pulse flour and $0.05 \mathrm{~g}$ soil were added into $100 \mathrm{ml}$ water and $2 \mathrm{~g}$ agar agar.

Jeevaamrut -2 amended plain agar media(as per above) $-5 \mathrm{~g}$ cow dung, $5 \mathrm{ml}$ cow urine, $1 \mathrm{~g}$ jaggery, $1 \mathrm{~g}$ pulse flour and $0.05 \mathrm{~g}$ soil were added into $100 \mathrm{ml}$ water and $2 \mathrm{~g}$ agar agar.

Jeevamrut - 3 amended plain agar media(as per above)-7.5 g cow dung, $2.5 \mathrm{ml}$ cow urine, $1 \mathrm{~g}$ jaggery, $1 \mathrm{~g}$ pulse flour and $0.05 \mathrm{~g}$ soil were added into $100 \mathrm{ml}$ water and $2 \mathrm{~g}$ agar agar.

Fresh cow dung $-2.5 \%$ amended plain agar media-2.5 g cow dung was added into $100 \mathrm{ml}$ water and $2 \mathrm{~g}$ agar agar

Fresh cow dung - 5\% amended plain agar media-5 g cow dung was added into $100 \mathrm{ml}$ water and $2 \mathrm{~g}$ agar agar

Fresh cow dung $-7.5 \%$ amended plain agar media-7.5 g cow dung was added into $100 \mathrm{ml}$ water and $2 \mathrm{~g}$ agar agar

Cow urine(old) $-2.5 \%$ amended plain agar media- $2.5 \mathrm{ml}$ cow urine was added into 100 $\mathrm{ml}$ water and $2 \mathrm{~g}$ agar agar

Cow urine(old) - $5 \%$ amended plain agar media-5 ml cow urine was added into $100 \mathrm{ml}$ water and $2 \mathrm{~g}$ agar agar

Cow urine(old) $-7.5 \%$ amended plain agar media-7.5 ml cow urine was added into 100 $\mathrm{ml}$ water and $2 \mathrm{~g}$ agar.

Pulse flour $-1 \%$ amended plain agar media-1 g pulse flour was added into $100 \mathrm{ml}$ water and 2 g agar agar

Jaggery - $1 \%$ amended plain agar media-1 g jaggery was added into $100 \mathrm{ml}$ water and $2 \mathrm{~g}$ agar agar.

\section{Untreated control}

The above mentioned media were prepared and sterilized in autoclave at $121^{\circ} \mathrm{C}$ temperature and 15 Psi pressure for 15 
minutes and they were evaluated under invitro conditions on plain agar medium by poisoned food technique.

Plain agar medium was amended with various inputs in required quantities before autoclaving at pre requisite concentrations. 20 $\mathrm{ml}$ of organic inputs amended medium was poured in each $90 \mathrm{~mm}$ sterilized Petri-plates and allowed to solidify. The plates were aseptically inoculated with $5 \mathrm{~mm}$ disc cut from the periphery of 7-days-old actively growing culture of $A$. alternata and a suitable control without organic inputs was maintained for comparison. The experiment was conducted in completely randomized design (CRD) with five replications in each treatment and the inoculated plates were incubated at $27 \pm 2^{\circ} \mathrm{C}$. The colony diameter was measured after 7 days when the control plates were full of fungal growth. Per cent inhibition of mycelial growth was calculated by using formula given by Bliss (1934) as:

$\mathrm{I}=\frac{C-T}{c} \times 100$

Where, $\quad I=$ Per cent inhibition

$\mathrm{C}=$ Colony diameter in control

$\mathrm{T}=$ Colony diameter in treatment

Standardization of Jeevamrut in-vivo against Alternaria leaf spot of mungbean under organic pot culture on inoculated plants.

Different treatment solutions of Jeevamrut and its constituents were prepared as mentioned below and were assessed against A. alternata as spray applications for management of Alternaria leaf spot. Pot experiments were laid out in completely randomized design (CRD) with three replications separately for each of the treatments to manage the disease on susceptible local mungbean landrace in Kharif, 2017 in the cage house, at Department of Plant Pathology, RCA Udaipur. Mungbean plants were raised in $30 \mathrm{~cm}$ earthen pots having Sand, Soil and FYM (3:1:1) mixture from organic field where organic farming is practiced for past six years. Five to six plants were maintained in each pot. Inoculations were made with a spore suspension of inoculum concentration of $1 \times 10^{3}$ conidia $\mathrm{ml}^{-1}$ for A. alternata on 50 day-old-plants. After 36 hours of inoculation of the pathogen, foliar applications of solutions of Jeevamrut-1, Jeevamrut-2 and Jeevamrut-3, cow dung, cow urine at 2.5, 5.0 and 7.5per cent, pulse flour and jaggery at 1.0 per cent concentrations were made (the constituents were kept in same proportion as discussed in in-vitro studies). For comparison inoculated control was maintained without organic input application.

\section{Preparation of different solutions}

Jeevamrut-1- It was prepared by taking $125 \mathrm{~g}$ fresh cow dung, $375 \mathrm{ml}$ cow urine (old), $50 \mathrm{~g}$ black jaggery, $50 \mathrm{~g}$ pulse flour and $2.5 \mathrm{~g}$ soil mixed with 51 of water. Solution was kept for 2-7 days in shade for fermentation. During fermentation, the solution was stirred daily. The lid of the container should be kept loose. After which it was used for spraying.

Similarly, Jeevamrut-2 and Jeevamrut-3 solutions were prepared by taking $250 \mathrm{~g}$ and $375 \mathrm{~g}$ fresh cow dung respectively and by taking $250 \mathrm{ml}$ and $125 \mathrm{ml}$ cow urine (old) respectively. Amount of rest other components remained same as that of Jeevamrut-1.

Fresh cow dung solution (2.5\%) - $125 \mathrm{~g}$ fresh cow dung was mixed with 51 of water. It was kept for 2-7 days. After which it was used for spraying.

Fresh cow dung solutions of 5 per cent and 7.5 per cent were prepared by taking $250 \mathrm{~g}$ and $375 \mathrm{~g}$ of fresh cow dung respectively with same procedure followed as in case of cow dung solution $(2.5 \%)$. 
Cow urine solution (2.5\%) - $125 \mathrm{ml}$ of several months old cow urine was mixed with 51 of water. It was kept for 2-7 days. After which it was used for spraying.

Similarly, cow urine solutions of 5 per cent and 7.5 per cent were prepared by taking 250 $\mathrm{ml}$ and $375 \mathrm{ml}$ of cow urine (several months old) in 51 of water.

Pulse flour solution (1\%) - $50 \mathrm{~g}$ of pulse flour was mixed with 51 of water. It was kept for 27 days. After which it was used for spraying.

Jaggery solution (1\%) - $50 \mathrm{~g}$ of jaggery was mixed with 51 of water. It was kept for 2-7 days. After which it was used for spraying.

Untreated control- 51 of water was taken without any organic input.

Observations of disease severity were recorded after 7 days of spraying above solutions, on a standard disease rating scale (1-5 score) given by Sangeetha and Siddaramaiah, 2007. The per cent disease index (PDI) and per cent efficacy of disease control (PEDC) were calculated by using following formula given by Chester, 1959 and Wheeler, 1969:

Per cent disease index (PDI)

Sum of all individual

disease rating

$=\frac{\text { disease rating }}{\begin{array}{l}\text { Total No. of plants } \\ \text { assessed } \times \text { maximum rating }\end{array}} \times 100$

PEDC $=\frac{\text { PDI in control }- \text { PDI treatment }}{\text { PDI in control }} \times 100$

\section{Results and Discussion}

Results revealed that Jeevamrut, cow dung and cow urine at all concentrations were significantly superior in inhibiting the mycelial growth of the fungus over control
(Table-1, Plate-2, Fig 1). Among the three solutions of Jeevamrut, Jeevamrut-2 was found most effective in inhibiting the mycelial growth $(93.34 \%)$ of A. alternata followed by Jeevamrut-1 (90.99\%) and Jeevamrut-3 (77.23\%). Among the constituents of Jeevamrut, cow urine at 7.5 per cent concentration was found to pose greater inhibition of mycelial growth of the test fungus $(92.23 \%)$ followed by cow urine $(5 \%)$ with mycelial growth inhibition of 91.67 per cent and cow urine $(2.5 \%)$ with mycelial growth inhibition of 86.34 per cent. Cow dung at 2.5 per cent, 5 per cent and 7.5 per cent concentrations caused mycelial growth inhibition of 86.23 per cent, 83.12 per cent and 67.23 per cent respectively. Little growth inhibition was found in case of pulse flour (1\%) with mycelial growth inhibition of 62.34 per cent. Jaggery was least effective in controlling mycelial growth of A. alternata. (15.77\% at 1 per cent concentration).

Among all maximum inhibition of mycelial growth $(93.34 \%)$ was recorded with Jeevamrut-2 followed by cow urine at 7.5 per cent concentration (92.23\%). Minimum inhibition of mycelial growth was recorded with jaggery at 1 per cent concentration $(15.77 \%)$ followed by pulse flour at 1 per cent concentration $(62.34 \%)$, respectively.

Results of pot culture study are revealed in Table 2. To manage Alternaria leaf spot of mungbean, all the treatments were found effective in suppressing the disease over untreated inoculated control. The maximum PDI 70.0 was observed in case of un-treated inoculated control. The lowest disease, with PDI 17.34 was recorded in plants with foliar spray of Jeevamrut-2 solution, which was found significantly superior as compared to all the other treatments (Plate 3) followed by Jeevamrut-1 with PDI 22.0 and Jeevamrut-3 with PDI 24.67. Maximum per cent efficacy of diseases control (PEDC) and minimum per 
cent efficacy of disease control (PEDC), for management of Alternaria leaf spot of mungbean, were observed in case of foliar spray of Jeevamrut-2 with PEDC 75.22 and that of jaggery with PEDC 18.08. Foliar application of Jeevamrut-2 resulted in significantly higher PEDC as compared to other treatments. Among remaining treatments, foliar spray with Jeevamrut-1 and Jeevamrut-3 resulted in PEDC 68.57 and 64.75 , respectively. The least per cent efficacy of diseases control was observed in case of jaggery (1\%) spray with PEDC 18.08 as compared to all other treatments. (Table-2, Plate-3).

\section{Significance of results}

Among different components and final product of Jeevamrut, Jeevamrut-2 with the protocol as suggested by Palekar (2006), was found most effective in inhibiting A. alternata in- vitro with mycelial growth inhibition of 93.34 per cent.

Its component cow urine has also significant inhibitory effect against the test pathogen with mycelial growth inhibition of 92.23 per cent at 7.5 per cent concentration. Present study seems to be the first one to test Jeevamrut against any pathogen.

Although, for its components, similar results have been reported by Nargis et al., (2007) who studied effect of cow dung and cow urine against Alternaria triticina and found 100\% conidial germination inhibition. Antifungal activity of cow urine was also reported against plant pathogens viz., Fusarium oxysporum, Alternaria helianthi and Cladosporium spp. by Patil (2007).

As Alternaria leaf spot of mungbean is a foliar disease and is present in different growth stages of the crop, need was felt to develop a location specific organic management strategy to reduce hazards of pesticide and to standardize Jeevamrut as there is lack of scientific evidence in support of development of exact protocols.

The present management studies, under artificial inoculations in pot cultures, revealed that the foliar spray of Jeevamrut-2 with the protocol as suggested by Palekar (2006) was found to manage the disease effectively and gave maximum PEDC of 75.22 followed by Jeevamrut-1 with PEDC (68.57). However, similar attempts have been reported by Reddy and Padmodaya (1996) by using panchgavya against soil borne pathogen Fusarium oxysporum f.sp. lycopersici, a causal agent of tomato wilt.

He found that panchgavya-3 (MPG-3) was superior to carbendazim in reducing the plant disease and in increasing the vigour of plant and yield. Hurali and Patil (2009) investigated the effect of panchgavya (3 per cent), cow urine (10 per cent), butter milk ( 2 per cent), cow milk (10 per cent) and vermiwash (50 per cent) against soybean rust. Cow urine resulted in reduced disease index (36.0 per cent) followed by butter milk (39.5 per cent), cow milk (40.8 per cent), panchgavya (41.5 per cent) and vermiwash (43.1 per cent).

\section{Interpretation of results}

This information is useful to manage the disease by natural means and can be used for similar diseases of other crops. However, attempts to manage the disease through on farm by products or ITKs (Indigenous Technical Knowledge) like Jeevamrut, cow dung and cow urine in present study were found to be effective. There is need to study the inclusion of these on farm by products to develop natural management strategy for effective and sustainable management of Alternaria leaf spot of mungbean in eco friendly approach 
Table.1 in vitro evaluation of different components and final product of jeevamrut against $A$. alternata after 7 days at $27 \pm 2{ }^{\circ} \mathrm{C}$

\begin{tabular}{|c|c|c|c|}
\hline S. No. & Treatments & $\begin{array}{l}\text { Colony } \\
\text { diameter }(\mathbf{m m}) *\end{array}$ & $\begin{array}{l}\text { Per cent growth } \\
\text { inhibition** }\end{array}$ \\
\hline 1 & Jeevamrut-1 & 8.10 & $90.99(72.58)$ \\
\hline 2 & Jeevamrut-2 & 6.00 & $93.34(75.14)$ \\
\hline 3 & Jeevamrut-3 & 20.50 & $77.23(61.48)$ \\
\hline 4 & Fresh cow dung- $2.5 \%$ & 12.40 & $86.23(68.22)$ \\
\hline 5 & Fresh cow dung-5\% & 15.20 & $83.12(65.71)$ \\
\hline 6 & Fresh cow dung-7.5\% & 29.50 & $67.23(55.07)$ \\
\hline 7 & Cow urine (old)-2.5\% & 12.30 & $86.34(68.30)$ \\
\hline 8 & Cow urine (old)-5\% & 7.50 & $91.67(73.28)$ \\
\hline 9 & Cow urine (old)-7.5\% & 7.00 & $92.23(73.79)$ \\
\hline 10 & Pulse flour- $1 \%$ & 33.90 & $62.34(52.12)$ \\
\hline 11 & Jaggery-1\% & 75.80 & $15.77(23.39)$ \\
\hline \multirow[t]{2}{*}{12} & Untreated control & 90.00 & 0.00 \\
\hline & $\begin{array}{l}\text { SEm } \pm \\
\text { CD at } 5 \% \\
\text { CV } \%\end{array}$ & $\begin{array}{l}0.574 \\
1.636 \\
4.838\end{array}$ & $\begin{array}{l}1.032 \\
3.045 \\
2.322\end{array}$ \\
\hline
\end{tabular}

* Mean of five replications

Table.2 Standardization of jeevamrut in vivo against Alternaria leaf spot of mungbean under organic pot culture on artificially inoculated plants

\begin{tabular}{|l|l|c|c|}
\hline S. No. & Treatments & $\begin{array}{c}\text { Per cent Disease Index } \\
\text { (PDI*) }\end{array}$ & $\begin{array}{c}\text { Per cent Efficacy } \\
\text { of Disease Control } \\
\text { (PEDC**) }\end{array}$ \\
\hline $\mathbf{1}$ & Jeevamrut-1 & $22.00(27.96)$ & $68.57(55.89)$ \\
\hline $\mathbf{2}$ & Jeevamrut-2 & $17.34(24.60)$ & $75.22(60.12)$ \\
\hline $\mathbf{3}$ & Jeevamrut-3 & $24.67(29.76)$ & $64.75(53.56)$ \\
\hline $\mathbf{4}$ & Fresh cow dung-2.5\% & $44.00(41.53)$ & $37.14(37.53)$ \\
\hline $\mathbf{5}$ & Fresh cow dung-5\% & $38.67(38.43)$ & $44.75(41.96)$ \\
\hline $\mathbf{6}$ & Fresh cow dung-7.5\% & $27.34(31.51)$ & $60.94(51.30)$ \\
\hline $\mathbf{7}$ & Cow urine (old)-2.5\% & $30.67(32.15)$ & $56.18(48.53)$ \\
\hline $\mathbf{8}$ & Cow urine (old)-5\% & $28.34(31.08)$ & $59.51(50.46)$ \\
\hline $\mathbf{9}$ & Cow urine (old)-7.5\% & $26.67(30.63)$ & $61.90(51.87)$ \\
\hline $\mathbf{1 0}$ & Pulse flour-1\% & $54.00(47.27)$ & $22.85(28.54)$ \\
\hline $\mathbf{1 1}$ & Jaggery-1\% & $57.34(49.20)$ & $18.08(25.15)$ \\
\hline $\mathbf{1 2}$ & Untreated control & $70.00(56.78)$ & 0.00 \\
\hline & SEm \pm & 0.621 & 1.013 \\
& CD at 5\% & 1.824 & 2.990 \\
\hline
\end{tabular}

* Mean of three replications 
Fig.1 In vitro evaluation of different components and final product of jeevamrut against $A$. alternata after 7 days at $27 \pm 1^{\circ} \mathrm{C}$



Figures in parentheses are arcsine $\sqrt{ }$ per cent angular transformed values.

Fig.2 Standardization of jeevamrut In vivo against Alternaria leaf spot of mungbean under organic pot culture on artificially inoculated plants

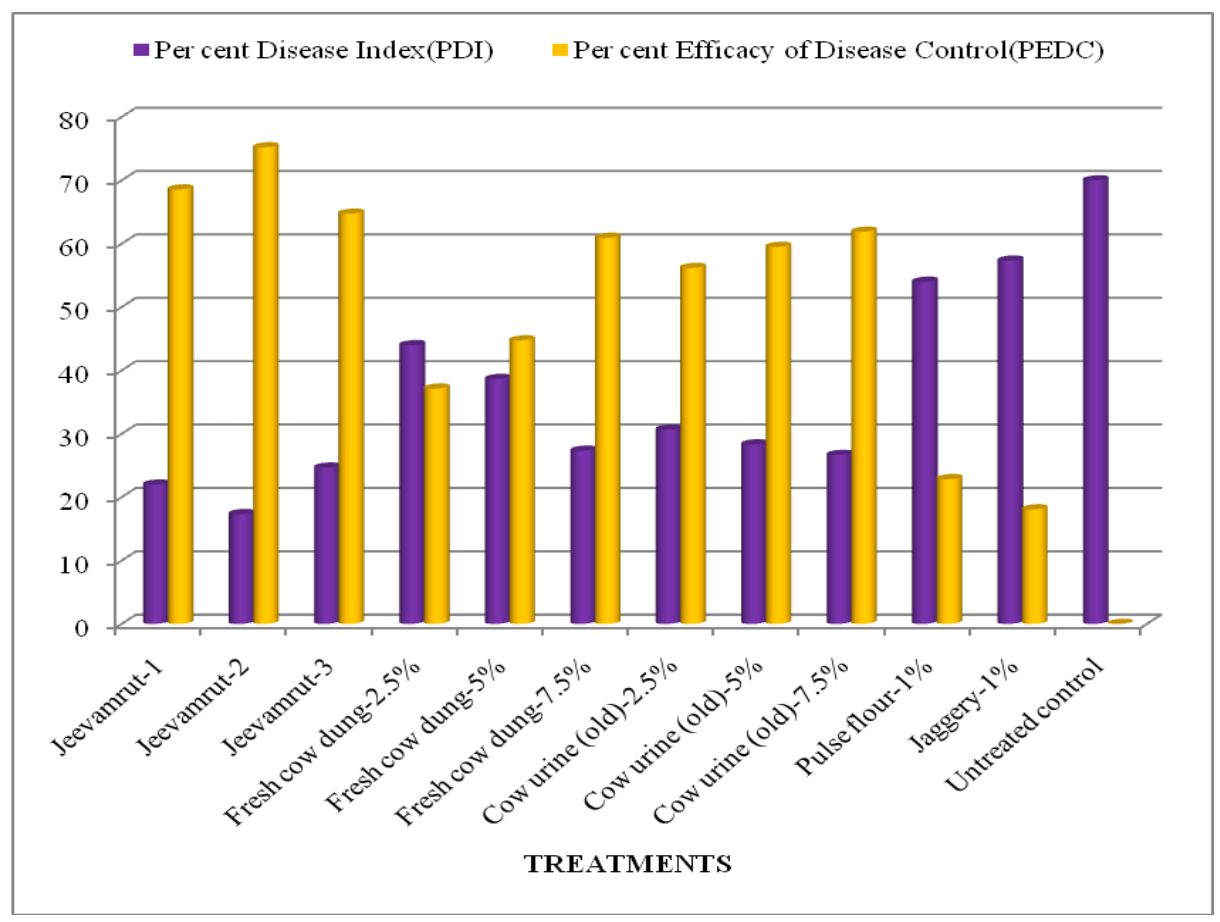


Plate.1 Pathogenecity of Alternaria alternPPlate1: Pathogenecity of Alternaria alternata on Mungbean


a. Diseased plant

b. Typical symptoms produced by A.alternata

c-d. Symptoms on leaves

e. Pure culture of A. alternata

f. Conidia in $40 \mathrm{X}$ of Microscope 
Plate.2 in vitro Evaluation of different components and final product of Jeevamrut against $A$. alternata after 7 days at $27 \pm 2^{\circ} \mathrm{C}$
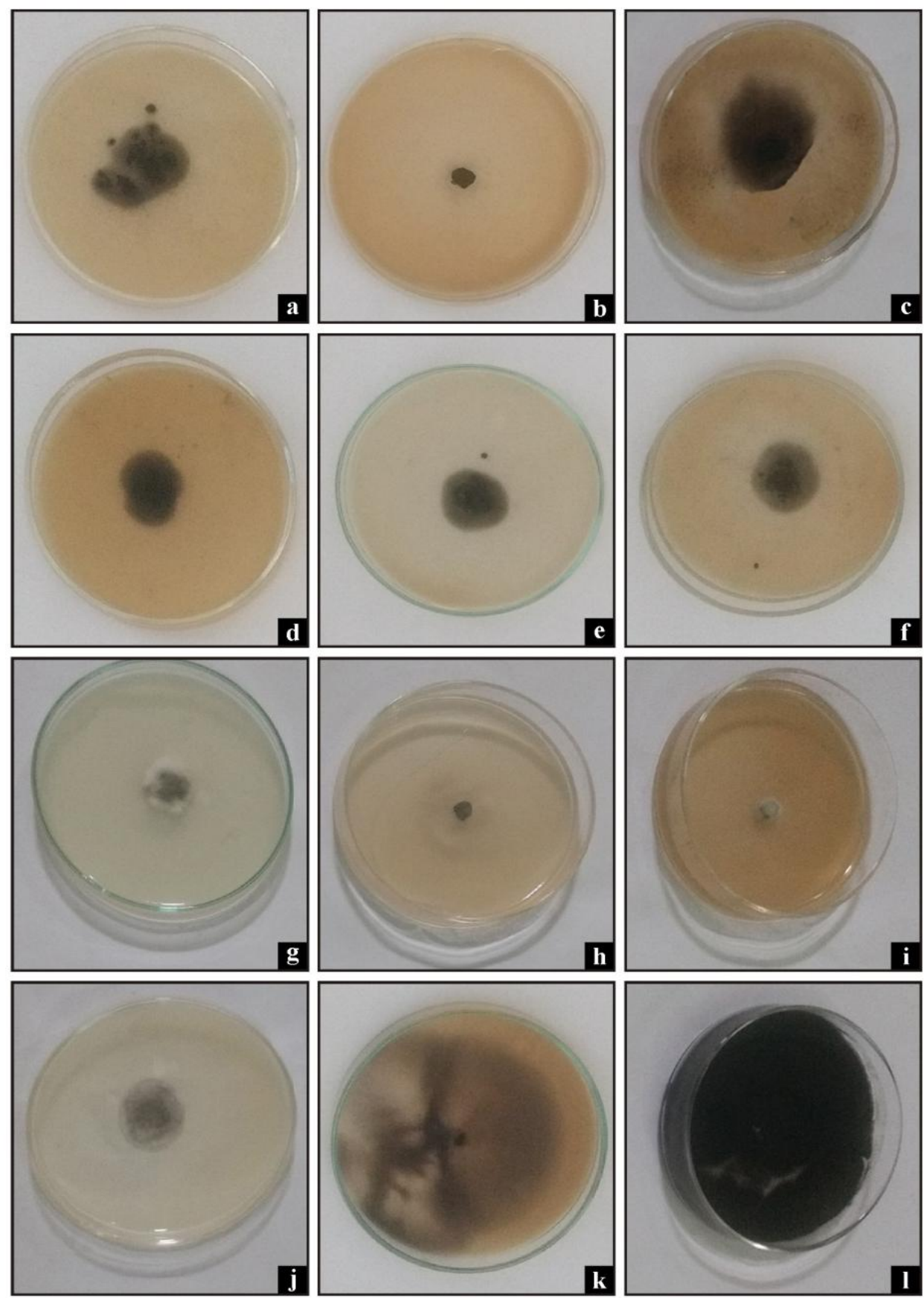

a. Jeevamrut-1; b. Jeevamrut-2; c. Jeevamrut-3; d. Fresh cow dung-2.5\%; e. Fresh cow dung-5\%; f. Fresh cow dung-7.5\%; g. Old cow urine-2.5\%; h. Old cow urine-5\%; i. Old cow urine-7.5\%; j. Pulse flour-1\%; k. Jaggery-1\%; 1 . Untreated control. 
Plate.3 Standardization of Jeevamrut in vivo against Alternaria leaf spot of mungbean in inoculated plants under organic pot culture
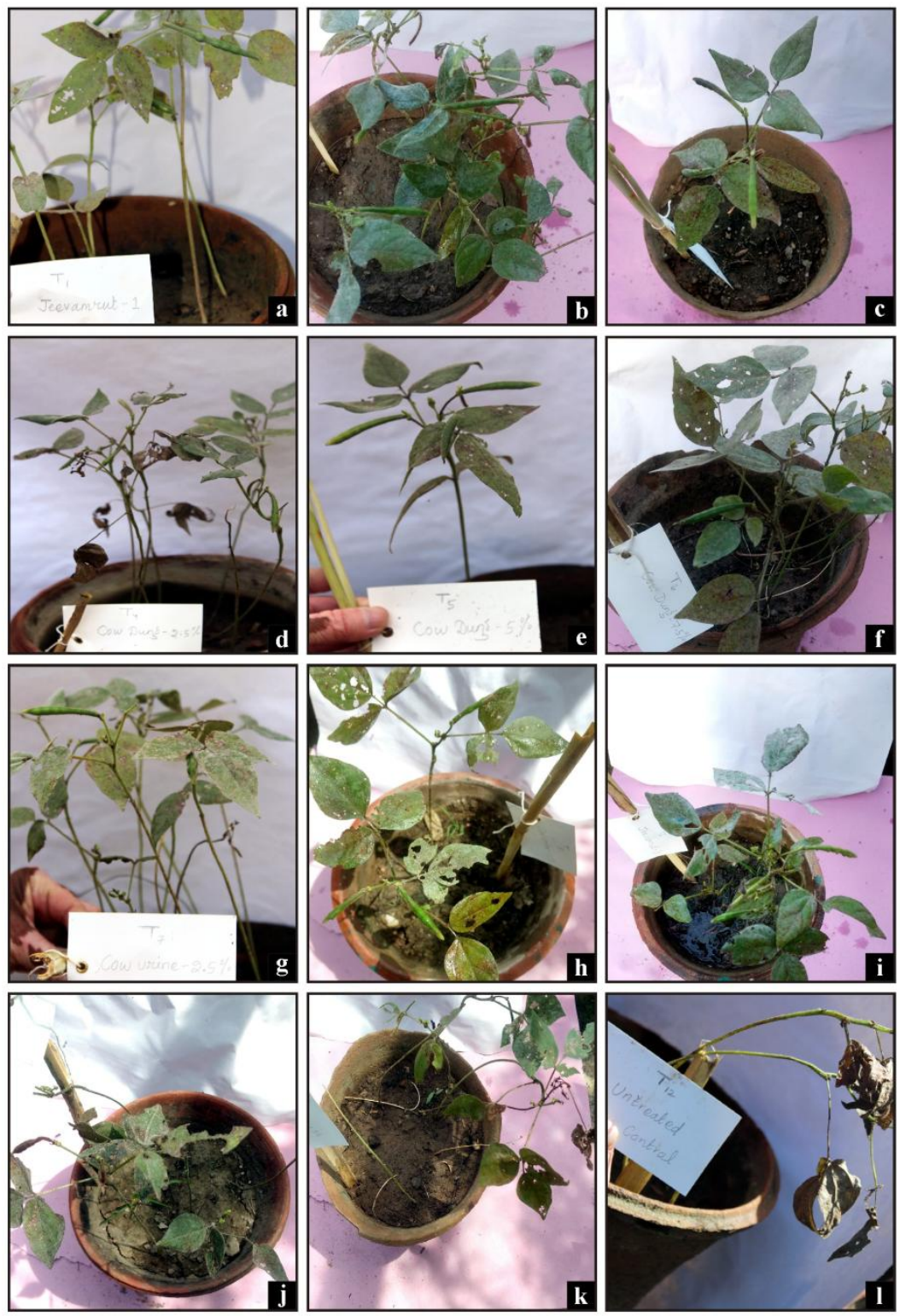

a. Jeevamrut-1; b. Jeevamrut-2; c. Jeevamrut-3; d. Fresh cow dung-2.5\%; e. Fresh cow dung-5\%; f. Fresh cow dung-7.5\%; g. Old cow urine-2.5\%; h. Old cow urine-5\%; i. Old cow urine-7.5\%; j. Pulse flour-1\%; k. Jaggery-1\%; 1. Untreated control.

\section{References}

Anonymous, 2016. Directorate of Pulses Development, VIth floor, Vindyachal bhavan, Bhopal - 462004. http://www.dpd.gov.in.

Basak, A.B., M.W. Lee and Lee, T.S. 2002.
Inhibitive Activity of Cow Urine and Cow Dung against Sclerotinia sclerotiorum of Cucumber. Mycobiol. 30: $175-179$.

Bliss, C.I. 1934. The method of probits. Science 79, 38.

Chester, K.S. 1959. How sick is the plant In: 
Plant Pathology Vol.1 (Eds.) J.G..Horsfall and A.E. Diamond. Academic Press, New York. pp. 199242.

Gupta, B.M. 1970. New disease on mungbean from Udaipur, Rajasthan, India. Plant Dis. Rep. 54: 453.

Hurali, M.K. and Patil, P.V. 2009. Impact of indigenous technology knowledge on enzymatic activity as influenced by rust of soybean. Karnataka J. Agric. Sci. 22: 340-343.

Nargis, A., Begum, M.F., Alam, S. and Alam, M. S. 2007. Inhibitory effect of different plant extracts, cow dung and cow urine on conidial germination of Bipolaris sorokiniana. J.bio-sci. 14: 87-92.

Palekar, S. 2006. Text book on Shoonya Bandovalada naisargika Krushi, Swamy Anand Agri Prakashana, Bangalore., pp. 98.

Patil, H.S.R. 2007. Antifungal potency of Cow Urine. Res. Rev. Biosci. 1: 4-5.

Rakesh, K.N., Dileep, N., Nawaz, N. A. S., Junaid, S. and Kekuda, T.R.P. 2013. Inhibitory effect of cow urine extracts of selected plants against pathogens causing Rhizome rot of ginger. Sci. Technol. Arts Res. J. 2: 92-96.
Rao, V.G. 1965. Alternaria tenuis auct. in Bombay-Maharashtra. Mycopathol. et Mycol. Appl. 27: 257-260.

Reddy, G.S. and Gupta, B.M. 1974. Epidemiological studies of leaf spot of mungbean (Phaseolus aureus Roxb.) caused by Alternaria alternata (Fr.) Keissler. Labdev J. Sci. Technol. 12: 117-118.

Reddy, H. and Padmodaya, B. 1996. Highfive. Down to Earth, 5: 54-55.

Sangeetha, C.G. and Siddaramaiah, A.L. 2007. Epidemiological studies of white rust, downy mildew and Alternaria blight of Indian mustard (Brassica juncea (Linn.) Czern. and Coss.). African J. Agric. Res. 2: 305-308.

Simmons, E.G. 2007. Alternaria: an identification manual. $C B S$ Biodiversity Series, 6: 644.

Singh, D.P. 1995. Breeding for resistance to diseases in pulse crops In: Genetic Research and Education: Current Trends and Fifty Year. Indian Society of Genetics and Plant Breeding, New Delhi. pp. 339-420.

Wheeler, B.E.J. 1969. An Introduction of Plant Diseases,.John Willey \& Sons Ltd., London., pp. 301.

\section{How to cite this article:}

Snehika Pandia, Amit Trivedi, S. K. Sharma and Shravan Yadav 2019. Evaluation of Jeevamrut and its Constituents against Alternaria Leaf spot of Mungbean in-vitro and under Cage House Condition in Rajasthan. Int.J.Curr.Microbiol.App.Sci. 8(09): 2240-2251. doi: https://doi.org/10.20546/ijcmas.2019.809.258 